\title{
Effect of Organic Matter on Manganese Solubility
}

\author{
Emilene Andrade; Mário Miyazawa; Marcos A. Pavan* and Edson L. de Oliveira \\ Instituto Agronômico do Paraná (IAPAR), Caixa Postal 481, CEP 86001-970, Londrina - PR, Brazil
}

\begin{abstract}
The objective of this study was to re-evaluate some aspects of the relative importance of organic matter on Mn solubility in acid soil conditions. Field study showed that black oats, oil seed radish, elephant grass, lupin, leucaena, and coffee leaves serving as mulch decreased Mn solubility as compared with bare soil. The decrease in Mn solubility with plant mulch was related to increase in soil moisture content. Laboratory study showed that increasing temperature from 25 to $100^{\circ} \mathrm{C}$ increased Mn solubility and total soil organic carbon was little changed; from 150 to $200^{\circ} \mathrm{C}$ increased both Mn solubility and organic carbon oxidation, and up to $300^{\circ} \mathrm{C}$ decreased $\mathrm{Mn}$ solubility and stoped organic carbon oxidation. Aluminum solubility always increased with increasing temperature. Organic matter exerted a control in both Mn and Al solubilities in acid soils.
\end{abstract}

Key words: Plant residue, mu lch, organic carbon, heavy metal, micronutrient

\section{INTRODUCTION}

Lowering soil $\mathrm{pH}$ results an increase in the level of $\mathrm{Mn}$ in the soil solution as illustrated by Lindsay (1979). In addition to the $\mathrm{pH}$ effect, $\mathrm{Mn}$ is also rendered soluble by redox mechanism $(\mathrm{pH}+\mathrm{pe}=$ 20, see Lindsay, 1979). Thus, under acid conditions in well aerated soils Mn can become soluble and toxic to many plants. The basis for predicting $\mathrm{Mn}$ toxicity is less clear than that for $\mathrm{Al}$ toxicity because of oxi-reduction reaction and $\mathrm{pH}$ relationship in $\mathrm{Mn}$ chemistry. There are some evidences to indicate that soil preparation processes for laboratory analysis ( air-dry, oven-dry, temperature, storage, etc.) changes Sherman, 1945; Pavan \& Miyazawa, 1984; Miyazawa et al., 1991 and 1996). Therefore, the effectiveness of soil Mn extractants for predicting yields and $\mathrm{Mn}$ uptake responses can not be properly evaluated. A similar consideration may apply when the soil dries under field conditions, resulting an increase in Mn solubility and is likely to become toxic to plants. (Pavan \& Miyazawa, 1984). Some useful developments have been the recognition that organic complexation of $\mathrm{Mn}$ is the main mechanism to control $\mathrm{Mn}$ solubility (Miyazawa et al., 1993), and also that Mn-organic complexes may exert a control on the $\mathrm{Mn}$ activity/pH relationship, which makes then potentially important controllers of Mn solubility under acid conditions. A re-examination on the relative importance of organic matter to determine Mn solubility in acid soil conditions was therefore warranted.

\section{MATERIAL AND METHODS}

Two experiments were conducted under field and laboratory conditions.

Field study with mulch - The experiment was conducted at the Instituto Agronômico do Paraná

\footnotetext{
* Author for correspondence
} 
(IAPAR) experimental station at Londrina $\left(23^{\circ} 23 \mathrm{~S}, \quad 51^{\circ} 11^{\prime} \mathrm{W}\right.$, elevation $\left.600 \mathrm{~m}\right)$ in an intensively cultivated oxisol (Latossolo roxo distrófico-LRd, Brazilian soil classification or Typic Haplorthox, U.S. Soil Taxonomy). Table 1 shows the main chemical characteristics of the soil. Plant materials were: black oats (Avena strigosa), oil seed radish (Raphanus sativus), elephant grass (Penissetum atropurpureum), lupin (Lupinus angustifolius), leucaena (Leucaena leucocephala), and coffee leaves (Coffea arabica). Oats, radish, lupin, and leucaena were collected at flowering stage, and elephant grass and coffee leaves were collected at vegetable stage. Plant materials were placed on soil surface serving as mulch and allowed to dry and decompose. Oats, radish, lupin, elephant grass, leucaena, and coffee leaves were added at the following rates, respectively: 0.0 ( control $=$ bare soil ) 640,500 , $560,440,1500$ and $1300 \mathrm{~g} \mathrm{~m}^{-2}$. The treatments were arranged in a randomized block design with three replications. Each plot consisted of $2 \mathrm{~m} \times 2 \mathrm{~m}$. Soil samples were collected at 49, 55, and 64 days after the beginning of the experiment for moisture and $\mathrm{Mn}$ determinations.

Laboratory study with soil organic matter - Soil samples were collected in a depth of $0-20 \mathrm{~cm}$ from cultivated areas located at Londrina (LRd), Cascavel (LRa), Ortigueira (LEa), Palotina (Tre), Ponta Grossa (Ca-1), and Curitiba (Ca-2). Table 1 shows the chemical characteristics of the soils.

Tabela 1 - Chemical characteristics of soil.

\begin{tabular}{|c|c|c|c|c|c|c|}
\hline $\begin{array}{l}\text { Soil } \\
\text { Type }\end{array}$ & $\begin{array}{c}\mathrm{pH} \mathrm{CaCl} \\
0.01 \mathrm{M}\end{array}$ & Al & $\begin{array}{l}\mathrm{Ca} \\
\mathrm{cmo}\end{array}$ & $\begin{array}{l}\mathrm{Mg} \\
\mathrm{dm}^{-3}\end{array}$ & $\mathrm{~K}$ & $\begin{array}{c}\mathrm{C} \\
\mathrm{g} \mathrm{kg}^{-1}\end{array}$ \\
\hline LRa & 4,60 & 0.32 & 6.00 & 2.57 & 0.56 & 47.66 \\
\hline $\mathrm{Ca}-2$ & 5,20 &, 00 & 6,71 & 3,54 & 0,25 & 32,87 \\
\hline LRd & 4,20 & & 2,40 & 0,92 & 0,23 & 17,01 \\
\hline Tre & 4,90 &, 09 & 4,12 & 1,48 & 0,56 & 11,45 \\
\hline $\mathrm{Ca}-1$ & 4,50 &, 70 & 4,04 & 2,40 & 0,59 & 49,04 \\
\hline $\mathrm{LEa}$ & 5,70 & 0,00 & 7,06 & 1,93 & 0,53 & 26,70 \\
\hline
\end{tabular}

Soil materials were ar dried and ground to pass $1 \mathrm{~mm}$ sieve. Five grams of soil sample were transferred to porcelain crucible and dried at 60, $100,150,200,300$ and $400{ }^{\circ} \mathrm{C}$ for one hour. Then, soil samples were analyzed for $\mathrm{Mn}, \mathrm{Al}$ and total carbon. A control sample was carried out with moistened soil at field capacity and at room temperature $\left(25^{\circ} \mathrm{C}\right)$.

Analytical procedures - Mn was extracted with $1 \mathrm{~mol} \mathrm{~L} \mathrm{~L}^{-1} \quad \mathrm{NH}_{4} \mathrm{AO}_{\mathrm{c}}$ (pH 7.0) solution at $1: 10$ soil:solution ratio, $60 \mathrm{~min}$ of shaking time, and centrifuged at $2500 \mathrm{rpm}$ for $10 \mathrm{~min}$. Aluminum was extracted with $0.1 \mathrm{~mol} \mathrm{~L}^{-1}$ EDTPA pH 6.8. Manganese and $\mathrm{Al}$ were determined by ICP (Inductively Coupled Plasma). Total carbon was determined by the Walkley-Black method.

\section{RESULTS AND DISCUSSION}

Figure 1 shows the effect of mulch treatments on Mn solubility. For control plot, soil Mn increased with time, from 31.2 to $73.2 \mathrm{mg} \mathrm{kg}^{-1}$. Comparing with control plot (bare soil), all soil covers decreased drastically Mn solubility. After 64 days, black oats and coffee leaves were the most efficient plant materials to reduce Mn solubility.

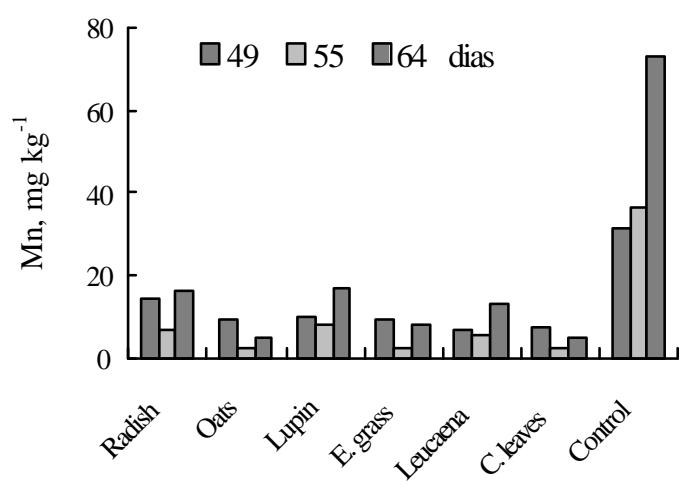

Figura 1 - The effect of mulches on Mn solubility.

The most likely explication for the effect of mulch on Mn solubility was associated with the conservation of high soil moisture (Figure 2). All plant materials increased the soil moisture content which was believed to decrease $\mathrm{Mn}$ solubility (Pavan \& Miyazawa, 1984).

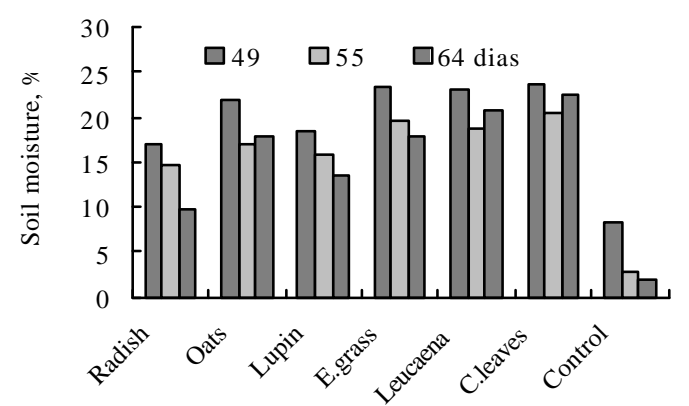

Figura 2 - The effect of plant mulches on soil moiture content.

This hypothesis can be clearly supported by the results show in Figure 3, which reveals a close 
relationship between soluble $\mathrm{Mn}$ and soil moisture content

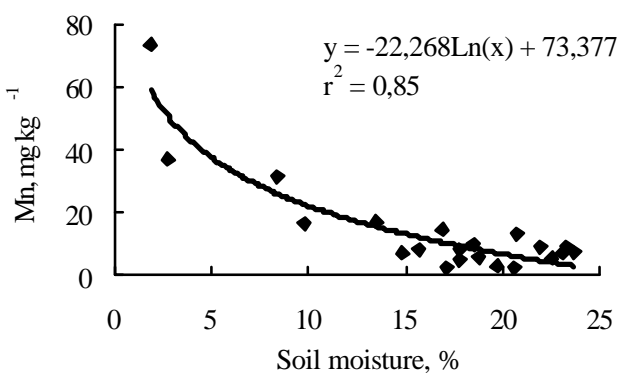

Figure 3 - The relationship between Mn solubility and soil moisture.

Second and third possibilities arose on soil temperature and sun light (data not shown). These were not unexpected since a complex interaction between Mn solubility/soil moisture/ soil temperature/ and sunlight could be anticipated (Miyazawa et al., 1996). These authors reported that increasing soil temperature and sunlight intensity increased Mn solubility. The decrease in Mn solubility with plant mulch could be important in the reduction of Mn toxicity in well aerated acid soil. The beneficial effect of mulch reported on coffee (Medcalf, 1956; Pavan et al., 1986) could be attributed to reducing $\mathrm{Mn}$ toxicity since $\mathrm{Mn}$ level in coffee leaves under soil covers was mostly very low when compared with bare soil. The effect of temperature on $\mathrm{Mn}$ solubility is shown on Figure 4.

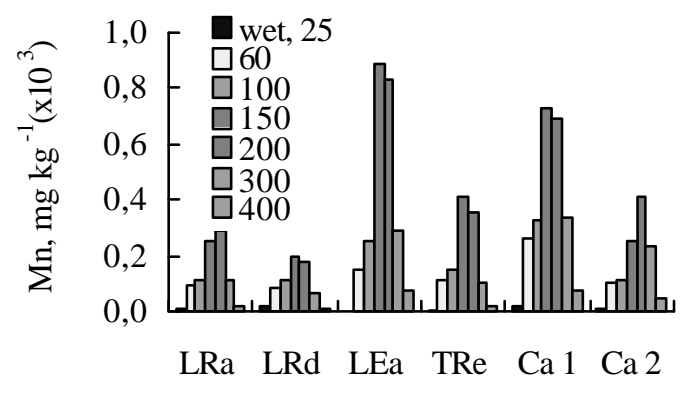

Soil type ( Brazilian classification)

Figura 4 - Temperature $\left({ }^{0} \mathrm{C}\right)$ effect on Mn solubility.

The concentration of $\mathrm{NH}_{4} \mathrm{AO}_{\mathrm{c}}-\mathrm{Mn}$ in soils at $25^{\circ} \mathrm{C}$ changed from 0.4 to $22.2 \mathrm{mg} \mathrm{kg}^{-1}$ as a function of soil type. Increasing temperature to $60^{\circ} \mathrm{C}$, normally used in laboratory to dry soil samples for fertility purpose, increased soluble Mn from 100 to $260 \mathrm{mg}$ $\mathrm{kg}^{-1}$ (LRa and Ca1, respectively). The highest Mn solubility was found at 150 and at $200^{\circ} \mathrm{C}(885$ and $827 \mathrm{mg} \mathrm{kg}^{-1}$, respectively) in LEa. Increasing $\mathrm{Mn}$ solubility with increasing temperature to $150-200$ ${ }^{0} \mathrm{C}$ has been well documented (Fujimori \& Sherman, 1945; Pavan \& Miyazawa, 1984; Miyazawa et al., 1991 and 1996). Increasing temperature up to $300{ }^{0} \mathrm{C}$ decreased drastically $\mathrm{Mn}$ solubility. On the other side, increasing temperature above $150^{\circ} \mathrm{C}$ decreased total carbon and at $400^{\circ} \mathrm{C}$, organic carbon was totally oxidized (Figure 5).

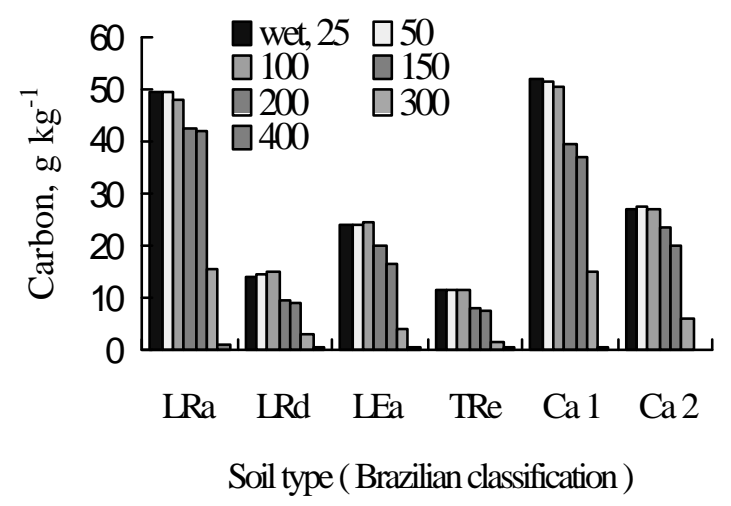

Figura 5 - Temperature $\left({ }^{0} \mathrm{C}\right)$ effect on organic carbon.

The solubility of $\mathrm{Mn}$ in relation to carbon oxidation showed three distinct regions. The first region (from 25 to $100^{\circ} \mathrm{C}$ ) showed an increased in Mn solubility with little change in carbon oxidation, probably as a result of thermical oxidation of Mn-organic complexes with high stability constants. The second region (from 150 to $200^{\circ} \mathrm{C}$ ), increased $\mathrm{Mn}$ solubility probably due to increase carbon oxidation. The third region (> $300^{\circ} \mathrm{C}$ ) decreased $\mathrm{Mn}$ solubility due to oxidation of $\mathrm{Mn}^{2+}$ released from the organic compounds to $\mathrm{MnO}_{2}$, changing the oxidation degree from $2^{+}$to $7^{+}$ rendering insoluble.

By comparing Mn solubility with other element, Figure 6 shows the effect of temperature on Al solubility. In contrast with $\mathrm{Mn}, \mathrm{Al}$ solubility followed organic carbon oxidation. As the oxireduction did not take place in $\mathrm{Al}$ chemistry, its concentration increased at temperature $>300^{\circ} \mathrm{C}$. Thus, Al-organic complexes was probably the main controlling factor in soil solution $\mathrm{Al}$ activity. It may simply be fortuitous that the level of exchangeable $\mathrm{Al}$ often correlates well with the amount of organic carbon in Brazilian soils (Pavan, 1983). Therefore the organic matter is an 
important controller of $\mathrm{Mn}$ and $\mathrm{Al}$ solubilities in well aerated acid soils.

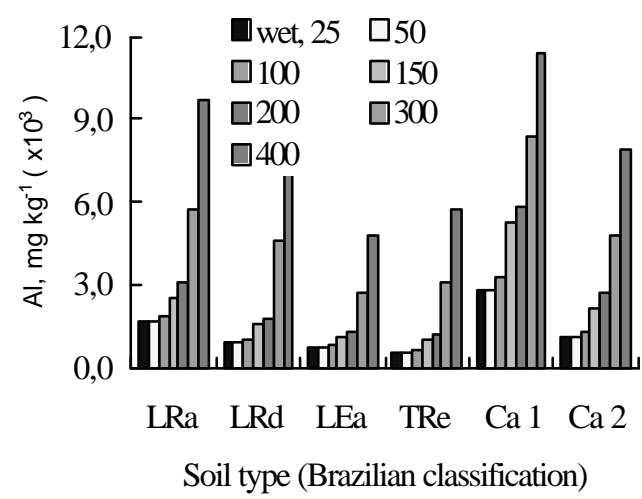

Figure 6 - Temperature $\left({ }^{0} \mathrm{C}\right)$ effect on $\mathrm{Al}$ soluble.

\section{RESUMO}

O estudo foi conduzido com objetivo de reavaliar alguns aspectos da importância relativa da matéria orgânica na solubilidade do $\mathrm{Mn}$ em solos ácidos. Em condição de campo cobertura morta com resíduos de aveia preta, nabo forrageiro, napier, tremoço, leucena e folhas de café diminuíram a solubilidade de Mn quando comparada com o solo descoberto. A redução na solubilidade do $\mathrm{Mn}$ em solo coberto com resíduos vegetais foi relacionada com o teor de umidade do solo. Estudos de laboratório demonstraram que o aumento da temperatura de 25 para $100^{\circ} \mathrm{C}$ aumentou a solubilidade do $\mathrm{Mn}$ com pouca alteração no teor de carbono do solo; de 150 a $200^{\circ} \mathrm{C}$ aumentou ambas a solubilidade do $\mathrm{Mn}$ e a oxidação do carbono orgânico e acima de $300^{\circ} \mathrm{C}$ diminuiu a solubilidade do $\mathrm{Mn}$ e completou a oxidação do carbono orgânico. A solubilidade do Al sempre aumentou com a elevação da temperatura. A matéria orgânica influenciou diretamente a solubilidade do Mn e do Al.

\section{REFERENCES}

Fujimori, C. K. and Sherman, G. C. (1945), The effect of drying, heating, and wetting on the level of exchangeable manganese in Hawaiin soils. Soil Sci. Soc. Am. Proc., 10, 107-112.

Lindsay, W. L. (1979), Chemical equilibria in soils. New York, John Wiley \& Sons. pp.449.

Medcalf, J. C. (1956), Estudos preliminares sobre aplicação de cobertura morta em cafeeiros novos no Brasil. São Paulo, IBEC Research Institute, pp.59. (Boletim, 12),

Miyazawa, M.; Pavan, M. A. and Martin Neto, L. (1993), Provável mecanismo de liberação do manganês no solo. Pesq. Agropec. bras., 28, 725-731.

Miyazawa, M.; Pavan, M. A.; Bloch, M. F. M.; Martin Neto, L. and Araujo, A. R. de. (1991), Efeito da temperatura de secagem do solo e extratores na solubilidade do manganês. $R$. bras. Ci. Solo, 15, 225227.

Miyazawa, M.; Pavan, M. A.; Machado, P. L. O. de A.; Oliveira, E. L. de and Yamashita, M. (1996), Manganese dynamic in acid soils and uptake by maize seedlings. Commun. Soil Sci. Pl. Anal., 27, 2349-2359.

Pavan, M. A. and Miyazawa, M. (1984), Disponibilidade do manganês no solo: dificuldades e problemas na interpretação da análise para fins de fertilidade. R. bras. Ci. Solo. 8, 285-289.

Pavan, M. A. (1983), Alumínio em alguns solos ácidos do Paraná. Relação entre o alumínio não trocável, trocável e solúvel com o pH, CTC, percentagem de saturação de Al e matéria orgânica. R. bras. Ci. Solo, 7, 39-46.

Pavan, M. A.; Caramori, P. H.; Androcioli Filho, A. and Scholz, M. F. (1986), Manejo da cobertura do solo para formação e produção de uma lavoura cafeeira. I. Influência na fertilidade do solo. Pesq. Agropec. bras., 21, 187-192.
Received: April 27, 2000; Revised: September 04, 2000; Accepted: April 02, 2001. 